\title{
French-Lithuanian Universe of Literary Critique by Greimas
}

\author{
LORETA MAČIANSKAITE்
}

\begin{abstract}
The idea for the present article came from the doubt expressed in the thesis of the world-renowned Algirdas Julius Greimas (1917-1992) that there is an unbridgeable gap between his Lithuanian essays and French semiotics. The analysis of texts written in Lithuanian in 1943-1955, dedicated to Cervantes, Verlaine, and Corneille unveils the most important methods of his analytical work: prioritizing the text over its context; the aim to uncover the author's authenticity. Greimas used the model of structural similarities between French and Lithuanian literatures for constructing Lithuanian literary history. In his estimation of Lithuanian poets, Greimas aimed at finding authors of the European level; a principle of analogies is fruitfully used for understanding their works. Lithuanian essays show that Greimas also wrote them as a semiotician. Some of Greimas's contemplations about literature also indicate the limits of his thinking, but the body of his works still reveals a surprising integrity of his personality.
\end{abstract}

Keywords: Lithuanian literature; French literature; Europeanism; semiotics; essay; literary history

\section{Foreword}

Algirdas Julius Greimas (1917, Tula-1992, Paris), a world-renowned linguist and semiotician, who proposed an interdisciplinary research program that attracted students from various countries and who developed his own method often called the Parisian school of semiotics, is known worldwide as a French scholar. But for Lithuanians Greimas is a researcher of mythology, an essayist who wrote on various topics of cultural, social and political life, a passionate polemicist, and one of the best critics of Lithuanian literature, who challenged the adopted views of the author and the canon.

As a literary scholar he wrote for the Lithuanian expatriate press small texts which he called essays rather than semiotics. He emphasized the uniqueness of this genre - an introduction of an author into a discourse. His Lithuanian texts are clearly different from his serious French academic works where a literary work is analyzed with methodological rigor. It is often thought that 
Greimas's studies did not leave the framework of immanent analysis; however, a deeper understanding of his works shows something different - for example, the study Maupassant : La sémiotique du texte (Greimas 1983) not only tries out methodological instruments but works with the text according to the principle that "the study of a literary text inevitable raises the question of its situation within the sociolectal literary universe" (Greimas 1988: xxvi). Recognizing the traces of this intellectual trajectory in Greimas's Lithuanian essays will be one of the main goals of our research.

It is also interesting to try to understand the concept of Lithuanian literature that was not really developed by Greimas but rather reconstructed from his texts that were presented to foreign audiences. It is interesting to search for the points of intersection in the analysis of certain authors, where Greimas's prognoses and later literary reception did not match, all the while raising questions about Greimas's own unrealized inherited stereotypes or internal constraints internalized from a different culture. The demythization method propagated by Greimas himself - "to describe by asking what all of this means" (Greimas 1966: 16) should help in this case.

Another important aspect is the authors that Greimas chose. Of course, for Greimas the Western episteme was first of all associated with France - his second homeland; however, he was open to literatures of other countries. ${ }^{1}$ When choosing Lithuanian authors, Greimas cared about their Europeanism. In analyzing them he distanced himself from the Lithuanian context and raised questions that were relevant to the Parisian intellectual discourse of the time. In the discussion of essays dedicated to Lithuanian authors it is interesting to discover the "French point of view" from which Greimas looks at his favorite Lithuanian poets and to recognize the traces of the French school of semiotics that was still being developed.

The third aspect that interests us is the intersection of different cultures in Greimas. He attended one of the best German-style gymnasiums in Lithuania and studied law at Kaunas University. In 1936 he left to study linguistics in France. In 1939 Greimas returned to Lithuania to perform his military service, in 1940 he started teaching French and Lithuanian literatures in schools in Siauliai. In 1944 he started graduate studies at the Sorbonne in Paris. He began his academic career as a teacher at a French Catholic boarding school for girls

1 For example, in the study On Imperfection (Greimas 1987), in addition to the passage from Michel Tournier's novel Friday, or, The Other Island, he also analyzed the texts by the Italian Italo Calvino, Austrian Rainer Maria Rilke, Japanese Tanizaki Hunichiro, Argentinian Julio Cortázar. 
in Alexandria in Egypt. In 1965 he became professor at the École des Hautes Études en Sciences Sociales in Paris where he taught for almost twenty-five years. Although we do not aim to fully trace how the two narrative paths of being Lithuanian and being French intertwined in his life, we still hope to at least touch upon it.

\section{Searching for Instruments of Literary Analysis}

Let us start with Greimas's first article published in 1943 in the literary almanac of Šiauliai Varpai (Eng. The Bells) ${ }^{2}$ which was dedicated to the translation of Miguel de Cervantes's Don Quixote to Lithuanian. Greimas does not hide his aspirations to bring the work closer to the modern reader, while at the same time realizing that the reader feels "not only the gap that separates him from the heights of the ingenious thought", but also the "enormous disproportion between the author and his epoch on the one hand and his work on the other." (Greimas 1943: 222) The reviewer acknowledges that explaining the work by using the author's biography and interpreting the epoch is not possible even with the most sophisticated pen of a critic working according to Hippolyte Taine's principles of determinism. At this point we can clearly see Greimas's pedagogical intentions - exactly at the same time he was working as a teacher at a girls' gymnasium in Šiauliai. While in his article about Cervantes Greimas praises the translation by Pulgis Andriušis, he also expresses his concerns as a teacher about the communication between the genius of authors and the younger generation, drawing attention to the problem of translating grand texts:

Rare translations of earlier classics and dry, rudimentary literature textbooks only serve to frighten the young and scare them away from any interest in literature; after enthusiastically introducing Dante a more honest teacher of literature is fearfully forced to show himself as a charlatan, to prohibit the pupils from reading The Divine Comedy in Lithuanian. (Greimas 1943: 222) ${ }^{3}$

The review reveals Greimas's most important desire - for the Lithuanian culture to open up to the treasury of world literature and join the Western episteme, which in his text is metaphorically marked by the epigraph - a quote

2 See Broden 2011 for more information about Greimas's activity during the years of World War II.

3 Aurimas Pumputis translation in this and other citations. 
from Bernardas Brazdžionis's poem Per pasaulị keliauja žmogus (Eng. A Man Travels Through the World $)^{4}$.

Another early text by Greimas that has not lost its relevance is an article about the French poet Paul Verlaine published in the Varpai almanac. In his youth Greimas was an admirer of the poet, but later he was slightly embarrassed by his admiration, admitting Verlaine's sentimentality. It seems that when he came to write the text in question, Greimas had changed his poetic preferences: under the French influence (i.e. after studying in Grenoble), the value of neoromantic poetry for him was diminished; he started to admire the poets that managed to create autonomous, independent poetic worlds. Greimas considered Verlaine's poetry "the first purely formalistic revolution". This revolution did not manifest itself through a renewal of ideas but rather through a whole new selection of viewpoints and a new poetic language. The content of Verlaine's works is rather simple - for example, the poem can consist of a single blissful sigh - "ô bien-aimée”, and for such poetry to avoid becoming primitive, its plane of expression should be well organized. Using musical techniques, namely alliterations, assonances, certain combinations of words and syllables, Verlaine seeks to extract the vibrations of the human soul from the lingual instrument - and the reader cannot resist such an effect. "De la musique avant toute chose!" Verlaine boldly proclaims in his Art Poetique, claiming that everything else is just "literature" (Greimas 1944a: 445).

However, in Greimas's interpretation Verlaine's tendency to make language more akin to music is not completely separated from content - it is an "attempt to rebuild a destructed cosmogony" (Greimas 1944a: 440).

The third text is the article (Greimas 1955) Corneille aktualumas (Eng. The Contemporaneity of Corneille), which was probably also born of a certain pedagogical experience when Greimas was teaching French literature in a girls' college in Egypt. According to Greimas, the greatest harm was done to Corneille or his appreciation by the French literary historians, especially the indisputable authorities of the $19^{\text {th }}$ century who applied the concept of classicism to him. In their eyes, Corneille became an antecedent of classicism who did not understand Aristotle. In his explanation of Corneille's originality, Greimas discusses the unbelievable nature of his works as a conscious construct, describing which requires concepts other than classicism. According to Greimas, Baroque - the new aesthetic category adopted from Germany

4 "Through seas immortal and wide/And through white-headed mountains/Without asking for directions/He will come to the Nemunas dale". Translated by Aurimas Pumputis. 
and established in France around the 1950s, is changing the perspective of appreciating Corneille - what previously looked like weaknesses become valued and a poor classicist antecedent turns into a great Baroque writer. Another innovation of Greimas's interpretation is also evident - the criterion of an adequate reading code and compliance with the present. Interestingly, Greimas also calls the post-war epoch Baroque, claiming that Corneille's problematic of freedom and action is relevant to the modern man who could recognize the origins of a community theater in Corneille's dramas.

\section{Proposing the History of Lithuanian Literature}

In the post-war period it has become important for the Lithuanian diaspora to take care of the further functioning of Lithuanian literature and transfer their traditions to younger generations, also a need to present Lithuanian literature to the Western audiences. Greimas responded to the topical issues of that time in a number of articles where he also considered the more general issues of modeling cultural or literary history.

Greimas did not only criticize the stories written by others, he also tried to build his own story model which was undoubtedly influenced by Roland Barthes and their 15-year-long friendship. For example, already in 1953 for the interpretation of Juozas Kèkštas's works Greimas used concepts from Barthes's box of instruments by contrasting the terms "writing" (écriture) and style:

The frame of the conventional symbolism: it is the writing of a single generation, a single defined movement that reflects the revolutionary worldview and the romantic ethic. Sometimes the flowers of a personal style bloom in this frame. The flowers that are rooted deeply in the animal or plant-like style of existence of a prehistoric human - the relation between a living fabric and its surroundings. (Greimas 1991a: 417-418)

Greimas does not hide his methodological closeness to Barthes. On the contrary, Barthes-like thinking is developed as a paradigm of thought, suggesting seeing Lithuanian authors in it as well, and that way finding a place for unusual poets such as Algimantas Mackus by suggesting a key for their interpretation:

The Roland Barthes book Zéro degré de l'écriture, published around the fifties [Barthes 1953] crystalized a whole set of hanging issues of our epoch: Why did Rimbaud choose silence? Why was Mallarmé mesmerized by the white piece of paper on the desk? What is the worth of the Flaubert's form euphoria? Why could Camus write only one novel, already plagiarizing himself in the second? 
French-Lithuanian Universe of Literary Critique by Greimas

Is it at all possible to write anything without lying? Is it possible to achieve the "white" (Mackus says "unornamented") writing, is it possible to reconcile a person with his writing without waiting for the human to reconcile with history? (Greimas 1963: 113)

The concept of the history of Lithuanian literature is stressed in Greimas's article for Encyclopédie de la Pléiade, still unknown to the Lithuanian public (Greimas 1956). However, even earlier hints of a plan to write the history of Lithuanian poetry can be found in his letter (September 9, 1947) to a friend from the times of Grenoble, the poet Jonas Kossu-Aleksandravičius (Sverdiolas 2017: 206), where Greimas notes that he wants to create a distinctive, real understanding of literary evolution that would make the futurist Kazys Binkis the cornerstone of all post-war poetry.

In the Encyclopédie de la Pléiade article, the figure of the evangelical cornerstone suggests a search for architectural images which would allow to interpret literary history as a building - say, a castle ${ }^{5}$. At the center of this complex building is the most prominent and essentially the first Lithuanian poet Kristijonas Donelaitis (1714-1780) who dominates the center of the "majestic mural", and "the door to the ultimate realistic literature" is opened by the literary experiments of Kazys Binkis (1893-1942).

The image of the mural is represented by the figure of the "social screen": on one side of the screen Greimas puts Catholicism, and on the other the revolutionary poetry of the intellectuals of the left (the realization of national genius in the problematic of human existence is placed between these poles of tension in Kossu's neo-romantic poetry). Greimas's model of literary history is constructed as the unity of opposites - the authors and phenomena are grouped into opposing pairs, which are again placed according to the principles of structural equivalence:

- left vs. right;

- social vs. national themes;

- a metaphysical direction of Symbolism that searches for the perfect form vs. the musical and spontaneous version of Symbolism;

- literature capable of assuming responsibility for the values of the previously great nation vs. literatures committed to protecting the national genius incarnated in the slavery of centuries.

5 In discussing science, Greimas also uses a building metaphor: "And still this conventional building of science holds and does not crumble. Why? Because every new theorem, every new theory fits well like a palace brick, it contributes to the whole building." (Greimas 1991a: 386) 
Greimas not only articulates the synchronic contradictions in Lithuanian literature but at the same time seeks to find parallels with European phenomena (not necessarily of the same periods): accordingly, Metai (Eng. The Seasons) by Donelaitis is related to Hesiod and the works of James Thomson or Jacques Delille. Development of $20^{\text {th }}$-century poetry is interpreted according to the trajectories of French surrealism or German expressionism. Analogies between separate Lithuanian and French authors are noticed: Binkis is related to André Breton. Vincas Mykolaitis-Putinas, who in 1933 wrote a novel about a catholic priest titled Altoriu šešely (Eng. In the Shadow of Altars), is compared to the Christian writer Paul Bourget.

It may be surprising that some seemingly important authors did not get a place in the literary history palace "designed" by Greimas. Their selection was not determined by any specific criterion of aesthetic value or truth but rather by the logic of the construct, the coherence of internal elements which in Greimas's opinion can be considered the criterion of truth ${ }^{6}$. For Greimas, the most important is relevance to his system and there is no point in including as many authors and texts as possible, especially since this article for Encyclopédie de la Pléiade was intended for non-Lithuanian audiences and the significant figures of French literature were deliberately used as marks of recognition that guide the readers from another cultural paradigm. On the other hand, Greimas also looked for transnational-level Lithuanian poets and both the experience of a linguist and the perspective of the French intellectual context were used for justifying their value.

\section{Opening the Transnationality of Lithuanian poetry}

Greimas has contributed to the expansion of the canon of Lithuanian poetry by enlarging it with the works of expatriates Henrikas Radauskas (1910-1970), Algimantas Mackus (1932-1964) and Tomas Venclova (b. 1937).

In his review of Radauskas's book Strèle danguje (Radauskas 1950, Eng. Arrow in the Sky) Greimas describes this poetry as "the only way to speak of the world that cannot be spoken", claiming that the reader needs to learn the language of such poetry the same way he would learn a foreign language, mathematical or philosophical thinking (Greimas 1954: 20). Formulating two possibilities of researching poetry - the psychoanalytical and the structural ones, Greimas defines the researcher's objective as a phenomenological description

6 Greimas claims that "science becomes possible and its truths become truths because of its consistency, the contents of its claims and their coherence" (Greimas 1991a: 386). 
of poetic vocabulary, morphology and poetic syntax, bringing out the verbal values, highlighting main themes, structuring the author's world view. The Lithuanian semiotician Kęstutis Nastopka considers such a strategy of literary critique to be one of the first attempts to create guidelines for semiotic research and describes Greimas as "a semiotician before semiotics" (Nastopka 2017: 12). This analysis of Radauskas poetry is focused on the text itself, which makes it conceptually different from Greimas's early articles in Varpai where he paid a lot of attention to the author's biography and context. However, there is still a connection between this text and the text about Verlaine - he considers both poets as an epistemological tipping point. Viewing Radauskas as a revolutionary seems paradoxical - it seems that such a role should have been attributed to a futurist rather than a poet close to the classicist tradition; however, according to Greimas the revolution in poetry is carried out by an author who brings in a new conception of artistic language, rather than the one who advances the furthest in experimenting. Greimas's text suggests that in arts the revolutionaries are usually the outsiders of their own culture - an emotional 'barbarian' Verlaine opposed the rational French and started a poetic revolution, and the Lithuanian sensuality is balanced by an aesthete Radauskas.

In an article dedicated to a poet of the younger expat generation Algimantas Mackus, written before the semiotic period ${ }^{7}$, Greimas formulates the aim of his analysis - "to measure poetry in that empty space where the plane of expression intertwines with the plane of content in formalistic knots" (Greimas 1963: 114). For Greimas such research of the correlation of planes is not just an immanent analysis but also a way of identifying the conception of a person and his place in literary history. After discussing antiphrasis as the main stylistic figure that Mackus used, Greimas opens the problematic of meaning (content) negation and proposes the experience of the 20th century French literature as a kind of intellectual compass for understanding it:

One of the leaders of the French Nouveau Roman Alain Robbe-Grillet once told how the purpose of the literature produced by his generation differs from that of existentialist literature: the later, by denying the meaning of human and the world, makes them absurd; the new generation, on the contrary, thinks that even nonsense is a way of implying some meaning, the new generation implies not the meaninglessness of the world, but its non-meaningfulness. Algimantas Mackus is a poet because instead of talking about the world's non-meaningfulness he stylistically realizes this notion, in a way of antiphrasis. That is what

The beginning of the semiotic period is marked by the Greimas's book Sémantique structurale: recherche et méthode, Larousse, 1966. 
makes him not a poet of absurdity, but a poet of non-meaning. (Greimas 1963: 114-115)

Greimas also uses the French reference point for understanding Tomas Venclova making an example of Stéphane Mallarmé's poetry, which is a "contemplation about writing" and according to whom all themes of modern writing "lead to the only problem of death" (Greimas 1972: 16). In the review of Venclova's first book of poetry Kalbos ženklas (1972, Eng. A Sign of Speech), published before his emigration, Greimas comes to the conclusion that in Venclova's works poetry itself - "linguistic structures, built on the line between being and nothingness" (Greimas 1972: 17) - is treated and acts as a vital protest against the weariness of life and as a method to resist the entropy of meaning.

In the article dedicated to the poem Ašara, dar tau anksti (Eng. Tear, It Is Too Soon for You) of the Lithuanian author from the Soviet period Marcelijus Martinaitis (1936-2013), Greimas explains and demonstrates his most important semiotic procedures (Greimas 1980: 44-73). His analysis traces a rather unexpected meaning of the poem - it is a search of addresser (Fr. destinateur), i.e. an actant, who directs the subject to his mission. Greimas unexpectedly relates this poem to eucharistic prayers that appeared in France after Vatican's second conclave. These religious texts are characterized by structural similarity to Martinaitis's poem and they rely on the concept of a modern Christian who wishes to believe but is not always capable of it. Providing the French context helps not only to problematize the question of faith considered in the poem but also to connect the experiences of looking for God from different countries into a single European paradigm of religious renewal which is characterized by the notion that "belief in non-belief, belief is a construction of an object that is believed in" (Greimas 1980: 73).

\section{Choices in the Opposition of the Own and the Alien}

Greimas's essays dedicated to Lithuanian literature and published in the expatriate press are characterized by their wide variety: among them there are some funny reviews that do not claim to be analytical at all, for example the ones that debunk the claim by a Soviet-Lithuanian poet Eduardas Mieželaitis to be an expert on French culture or the ones that make ironic fun of the Sovietized treatment of erotica in the series Žmogus (Eng. Human) which was awarded the Lenin Prize in 1962; there are also picturesque, emotional texts, especially the ones intended for friends of his youth (especially for Jonas 
Kossu-Aleksandravičius; his love from his Šiauliai period the poet Hania Lukauskaite; the poet and prose writer Kazys Boruta whom he compared to André Malraux).

Cold objectivity is not a characteristic of Greimas's texts about the works of his friend, the Samogitian nobleman and military officer Fabijonas Neveravičius (1900-1981). His unfinished series of historical novels that span six generations - Blaškomos liepsnos (Eng. Flinging Flames) (1936) and Erškéčiai (Eng. Thorns) (1937) - that turn back to the centenary of fighting for freedom in the Polish-Lithuanian Commonwealth were criticized in Lithuania for being distant from the paradigm of Lithuanian national history, estrangement from ethnical Lithuanian peasants and closeness to the Polish literary tradition. However, Greimas appreciated Neveravičius's attempt to include the heritage of the Polish-speaking nobility in the Lithuanian historical memory and restore the damaged historical and cultural continuity:

Neveravičius is a man to whom Lithuanian dukes are not enough, who understood both the necessity for a Lithuanian historical tradition, and that historical traditions do not make 500-year jumps. A descendant of the Samogitian race, whose grandparents fought for free Lithuania in the uprisings of the 18th and 19th centuries, he intuitively feels in his blood what another [...] could only understand after seeing Vilnius towers and twisted streets - that Lithuania existed even after Vytautas the Great, that we, as the rest of Europe, continued to live our history even after his failed coronation, that we had to take it for ourselves, identify it with the present and the future. (Greimas 1991a: 269)

However, Greimas's positive opinion of Neveravičius works that depict the present is no longer convincing: looking from a distance in time it is obvious that Greimas eagerly supported the attempts to apply a psychoanalytical method to Lithuanian prose and positively responded to some of his works solely because of their innovative European ambitions. It is interesting to see how in his review of Nevaravičius's collection Dienovidžio sutemos (1949, Eng. The Meridian Twilight) Greimas tries to support the author he sympathizes with, first praising him for bringing in new themes of the bourgeoisie or intelligentsia rather than sticking to the villagers of traditional Lithuanian literature. In the process, instead of performing an analysis of specific texts, Greimas starts deliberating about the inferiority of the novella as a genre and offers Honoré de Balzac as an example for the entire emerging Lithuanian novel tradition and as an alternative to the interwar Lithuanian prose. 
Similarly, Greimas's "diplomacy" is also visible in a letter (August 29, 1954) to the playwright Antanas Škema (1910-1961) who lived in New York and sent Greimas the drama Prabudimas (Eng. The Awakening), asking him to help mediate its staging in Paris. Škema's Prabudimas depicts former old friends who meet in an NKVD prison and tests each of them in "marginal situations". Not only does it leave no illusions about the Soviet system, but shows it as extremely brutal and cynical, capable of destroying even the left-wing intellectuals who gave up their lives for the ideals of communism. Here we should remember what happened after Albert Camus published L'Homme révolté (Eng. The Rebel) in 1951, opposing dictatorship and showing how there is practically no difference between fascism and Stalinism. Jean-Paul Sartre, who worked for Les Temps Modernes, denied Stalin's crimes and commissioned Francis Jeanson's article that attacked Camus which ended the friendship of these two left-wing intellectuals.

It seems that Greimas understood that mediating the staging of an anticommunist play in Paris in such a climate would at the very least be unreasonable (it could have cost him his own reputation), and he probably thought that the sensual and ambitious Lithuanian writer Škema would be insulted by these circumstances. Therefore, Greimas uses theatrical rather than political arguments, although admitting that he is not a theater critic:

With its plot your play reminds of Sartre's Les jeux sont faits and Emmanuel Roblès Montserrat. However, what separates them both from yours is that your play is psychological and those two are metaphysical. [...] The modern theater wants to be either philosophical or social, and the era of psychologism (plg. painting, poetry, music) is over. Your heroes, if I can say so, are moving towards life, backwards towards the future. [...] You might say that it is a humane or theatric truth. But the modern theater does not care about psychological truths, it is an illustration of certain existentialist attitudes and certain important social problems, and not the seeker of justice. (Sverdiolas 2017: 246)

Of course, such an opinion must have been very painful to Škèma as he knew a lot about Sartre and in the remarks concerning his 1950s play Pabudimas he even mentions him, along with Arthur Koestler, as a playwright recommended to the actors (although unlike Greimas, he emphasizes another of Sartre's plays, Les Mains sales (Eng. Dirty Hands)). By the way, Škema does not mention psychology anywhere in those remarks, on the contrary - he emphasizes the drama's symbolism, "the quintessence of our tragic epoch", and highlights the necessity of treating communism philosophically - as an expression of "the closing-in of the world" (Škema 1994: 538). So, Greimas's advice to avoid psychologism was already irrelevant to him. Just like the teachings about what modern theater 
should look like. In 1954 when the letter was written, Sartre no longer had the final word in the Parisian fashion of theater because of the appearance of the anti-play, absurd plays, Jean Genet, Eugène Ionesco, Samuel Beckett, all of whom Greimas did not mention and who were alien to his taste.

Greimas returned to Škèma in 1956 - as Pabudimas was finally published, the Lithuanian expatriate press started to accuse the author of immorality. In response to this, Greimas discusses the meaning of rape or sodomy scenes as a sign of the epoch's cruelty, this way not only vindicating Škema, but also offering the Lithuanian readers a previously critically unarticulated symbolic rather than the realistic literary reading code. Curiously, the contemplations about depicting love in literature which Greimas based on medieval hagiography (ironically Greimas described love with the trite image of "the mirror of society"), is developed into the problematic of the relationship between the text and the audience:

The real literature is not just an entertainment of the bored classes, much like any real art it is an autonomous, global plan of human expression, tied by dialectic relations to the plane of lived reality: a man loves or become holy according to the way of loving or becoming holy he learned from books, and books describe love or holiness - if they are good, real books - according to the social canons of love and holiness. (Greimas 1957a: 21)

In the same article, he remembers the expat Birutè Pūkelevičiūtè (1923-2007), a poet who is now universally recognized as an outstanding Lithuanian author but who in the 1960s was bashed by expat critics (including the liberals) for her 1952 book of poetry Metūgés where she openly expressed female eroticism. Greimas laconically compares her to the character of Škėma's Pabudimas - according to him she is the only "woman worthy of sin in Lithuanian literature, apart from Pūkelevičiūtè" - but does not comment on her works and goes into an ambiguous sexist discourse that would not be possible today: "thanks to a kind friend in the summer of last year in Paris I had a chance to turn over ${ }^{8}$, but it is a poet, not a literary character, therefore, I do not dare to go further down this slippery road (reason - wife)." (Greimas 1957a: 21) On the one hand, it seems strange that Greimas did not defend an author who could at that time even surprise many in the West with her innovativeness (although it seems that he did feel the power of her works); but on the other hand, we also have to recognize the undefeated

8 In the Lithuanian language the same word for "turning over" is used when talking about skimming through a book, turning over a thing and rolling in bed. In the quote Greimas plays with this ambiguity as it is not clear what he was 'turning over' - was it the book or the poet herself. 
patriarchal attitudes, some sort of a non-reflective solidarity with the male part of the diaspora, maybe even Škèma, who had an affair with Pūkelevičiūtè that was ended by her?.

The literary scholar Solveiga Daugirdaite considers Greimas's this particular passage as a tactic to undermine the literary achievements of women (Daugirdaite 2012: 64). Along with her, we would say that the idea of ingraining canons from books materialized in Greimas's own discourse of literary critique, giving away the remnants of his latent antifeminism.

The signs of inherited patriarchalism are also visible in an early text published in 1944 in Varpai - a review of Gražina Tulauskaitè book of poetry Vëjo smuikas (Eng. Violin of the Wind). Greimas makes a clear distinction between 'real' poetry and women's poetry, describing the latter as marginal and petty, but necessary to parts of society:

The glee of the nation's [...] poetry would be missing a lot if sometimes it was not parted by a soft, minor female voice, singing with great modesty and sincerity about the worries of its heart, the orphans' tears, the horrors of poverty, and search for happiness. Every nation's poetry has a rather clearly distinct space for a woman-poet, and there is a tone, speaking in which she excites greatly. (Greimas 1944b: 388)

Greimas mentions ${ }^{10}$ another representative of women's poetry - Salomèja Nèris, stating that "after we lost her" it seems that Tulauskaite was called to occupy the vacant place. In his interpretation Salomeja Neris is regarded as a woman-poet rather than simply a poet, forgetting that she was one of the stars among neoromantic poets and rival to the guru of Greimas's youth Kossu-Aleksandravicius (Kossu received the State Prize in 1937, Nèris in 1938). Greimas displays a sense of humor when he mocks the banal content and primitive expression of Tulauskaitë's works, linking these literary faults that are just as characteristic of

9 Pūkelevičiūtè played the main role of Elena in Škèmas's play Pabudimas which he directed in Mont Real in 1953.

10 The last name is not stated explicitly, however, from a few provided quotes the reader will easily recognize their author. Greimas laconically summed up Neris's "biographical story" - "we lost her", without going into detail about her dramatic life. She supported the Soviet regime, wrote the "Poem about Stalin", at the start of the war she had to escape from Lithuania or be convicted as traitor of the state. At the time of writing the article Neris lived in Russia and continued to write but Greimas did not know that - she died a year later in 1945. A political review of Neris is absent from Greimas's article, she only operates as an example of sophisticated female poetry. 
male romantic or neo-romantic works to the gender of the author and "hundreds of her sisters" (Greimas 1944b: 388).

The approach to women's nature articulated in the review should not come as a surprise as it was consistent with the cultural norms of the time; however, it is strange that Greimas authorized this text for re-publication in the early 1990s when preparing a series of texts for Iš arti ir toli (Eng. From Near and Far). At the end of the $20^{\text {th }}$ century, after two feminist waves, such subversive treatment of women's works would hardly be tolerated in the Western intellectual discourse; but in Lithuania, which was not yet familiar with feminism when Greimas's article was published, it did not pose any questions.

It is interesting that the decade-younger world-class scientist and sociologist Vytautas Kavolis (1930-1996) who grew up in America possessed no such patriarchal stereotypes and in 1992 read a series of lectures "Men and Women in Lithuanian Culture" to Lithuanians, initiating for them a paradigm shift in thinking about women's creative work.

In times of national revival Greimas did not return to Lithuania but sent his students to spread the ideas of semiotics while maintaining constant communication through the mail in which he proposed the future of Lithuania open to the West, supported the publishing of a journal of European culture, modelled two programs: (a) program of national orientation that was meant to integrate fifty years of memory; (b) a wide international "campaign of translations, which would bring close what happens in the world, although already late: Borges, Cortázar and the whole great South American literature, Joyce, Proust and the French Nouveau Roman" (Sverdiolas 2017: 328). However, Lithuanian literature itself no longer attracted his attention.

In a letter to his disciple Saulius Žukas (March $3^{\text {rd }}$, 1990) Greimas says that he received but did not read some contemporary works of Lithuanian literature translated into French, he thanks him for "expanding his horizons" and admits that he does not know contemporary literature at all (Sverdiolas 2017: 387). Still, lack of knowledge did not stop him from publicly, or in his letters, voicing negative opinions about some of the most well-known Lithuanian writers of the time who brought both Lithuanians and the expats the hope of joining the Western episteme. Greimas seemed to hold himself aloof and did not invest much effort into advertising the works of these authors in France, or even into reading them or trying to break this unusual to him literary code.

This is how he writes about the novel Žalčio žvilgsnis (1981, Eng. The Glance of the Serpent) by Saulius Tomas Kondrotas who emigrated from Lithuania in 1986 and after a few years published this novel's translation in France: 
I am reading the first chapter. I am trying to check a principle I formulated long ago that reading takes too much time, that it is enough to read the first ten pages and you know if the author is worthy of something or not. So the first pages are readable. Though, the faith and superstitions of the 19th century village are written in a literary way, but are accurate, they create an atmosphere, and that is something. Style - promises of good baroque. The author's lungs are good, he has breath.

I am reading further and some half mystical pseudo-oriental contemplations that show the Buddhist prayers seen by Berkeley some 68 years ago begin [...]. I lacked the patience to continue reading and left it for the next time. (Greimas 1991b: 6, Greimas 2012: 172)

A particularly unacceptable work for him was Ričardas Gavelis's novel Vilniaus pokeris (Eng. Vilnius Poker), published in 1989. The novel employed storytelling methods that were new to Lithuanian literature at the time and was partly inspired by James Joyce's Ulysses. For example, in his letter Greimas (1990 March $14^{\text {th }}$ ) writes to the philosopher Arvydas Šliogeris:

I read half of Gavelis's chef-d'oeuvre, I could not anymore. Somewhere I also read "the reviews" that it is the Lithuanian Joyce, that it is an epistemological tipping point! We lack not only modesty but even the commonsense feeling of proportions. [...] it seems that Lithuanians are still not able to respect, to love a woman's body. The same is with Gavelis: no sensuality, no sexuality, just a common privy pornography. And the most important - the art is lacking: of course you can also present shit in a nice way. - I am jumping to another topic: I read that the works of one old nice friend Fabijonas Nevaravičius will be reprinted in Vilnius - read how a gentleman writes. (Sverdiolas 2017: 379)

Greimas did not accept Gavelis's aesthetic of ugliness. However, in his famous French study L'Imperfection (1987) ugliness is considered an aesthetic category, and the situation of contemporary literature that appeared "after the unexpected disappearance of faith" is described as the "effectiveness" and "scandalousness" of art - the latest changes of taste and the hopeless wish to transcend that taste (Greimas 1987: 84). It is obvious that different evaluative standards are applied to French and Lithuanian literatures: there is not even an attempt to consider scandalousness or the structure of the novel that Gavelis had modeled on an analogy with the game of poker, there are no thoughts about the symbolic meaning of the pornographic scenes (as Greimas himself wrote in 1957, when defending Škema from accusations of immorality (Greimas 1957a: 20)). The categorical view of this novel as pornography was probably also determined by Greimas's personal attitude to the "ungentlemanly" writing that 
he had formed already in his youth, and the questions distant from Gavelis's work that interested him in the 1980s: conditions for cultural eroticism and sublimation, understood as a trajectory of partially relocating eroticism, when on the way to holiness it engenders aestheticism, as claimed by his student and second wife Teresa Mary Keane (Sverdiolas 2017: 501).

Not recognizing the value of Gavelis's work is one of the most impressive of Greimas's missteps. In the USA, the English translation of Vilniaus pokeris (Gavelis 2009) has been ranked among the top twenty-five of translated books, but the greatest success was achieved in France (Gavelis 2014), where he received over twenty-five reviews (and none of them questioned its value (Bikulčius 2016)). Radio and TV discussions followed, and the books were even labeled with stickers "Why didn't we know anything about this exclusive author for so long?” In France Gavelis was compared to Franz Kafka, LouisFerdinand Céline, William Faulkner, Charles Bukowski, George Orwell, László Krasznahorkai, Louis Calaferte, Hubert Selby, Vladimir Nabokov, Antonin Artaud, William S. Burroughs, Fernando Pessoa and others, but most often to James Joyce. Macha Séry, the book reviewer of Le Monde, calls Vilnius Poker a European novel that extends Ulysses and does not stop at discussing the motifs of wandering the city-labyrinth common between the two authors but also uses a textual argument - describing one of the characters as the "Circe of the crossroads" (Séry 2015).

Greimas's attitude to Lithuanian literature written in Soviet times is similar to the common position of Western critics concerning Eastern European literature. Criteria formed in their own environment are applied to literary works instead of trying to understand the specifics of the works by taking an interest in, rather than rejecting, their otherness. However, Greimas's failures of diagnosing literature are rather rare exceptions, as in most cases he was well aware of his times, especially in the 1960s to the 1980s.

\section{Conclusions}

Greimas has proposed that "the maturity of the West happens when two principles of the world's formations - the French-English and German-Russian, are fighting and complementing each other" (Greimas 1949b: 4). As shown by his biography, he demonstrated the possibility of such a synthesis with his own intellectual background. The personal experiences of World War II (service in several armies, anti-Nazi resistance, his parents' deportation, his own escape from Lithuania) formed Greimas's new transnational European identity and at the same time gave him the feeling of the absurd, of non-sense, which impelled 
him towards a quest for meaning (Broden 2011). The beginning of the genesis of this problematic is in the war-time Lithuanian article where he introduced Don Quixote as a type of a hopeless hero (Greimas 1991c: 44). The main guidelines for the future research are already visible in the early publications where he initiates the study of the correlation between the planes of expression and content (which will be very important in Greimas's semiotic period) and it is used as a tool for conceptualizing the history of literature.

Greimas's model of literary history, which was based on an approach to literary development as a story of emancipation from tradition and the fight against heritage, was later successfully complemented with the practice of searching for structural equivalents in Lithuanian poetry.

The analysis of Martinaitis's poem is considered to be the peak of Greimas's literary critique. For more than twenty years this text has been a mandatory one for the students of the Philology Faculty. The phrase from the ending of Martinaitis's essay "God I believe for you - help me with the non-belief!" (Greimas 1980: 73) repeats the phrase from the article about Don Quixote (Greimas 1943: 224). Such coherence of Greimas's texts shows the consistency of the author's thoughts.

Greimas's texts on Lithuanian literature require a great deal of reader's competence, not only the understanding of the current tendencies, but first of all the knowledge of canonical texts (both Lithuanian and global classics). Greimas's Lithuanian essays prove that for a literary scholar, even for one that prioritizes immanent analysis, the feeling of history and context is sine qua non.

Greimas's contemplations about historical novels, openness to the multicultural Lithuanian heritage and orientation towards epic European traditions are very important arguments for the still relevant questions of Lithuanian historical memory and expansion of the literary canon. This topic is even more relevant in contemporary Lithuania as the literature that started the genre of historiographic fiction and contains the Polish and French experience of novel writing is usually ignored.

It should be noted that Greimas was not oblivious to the challenges of his lifetime - he seriously considered the 1968 youth revolutions, the hippie anticulture and counter-culture; however, it seems that the movement for women's emancipation had passed him by without touching him ${ }^{11}$. Greimas's article in

11 Such an "antifeminist" view is based on some of Greimas's texts in Lithuanian; however, it is just a presumption that seems not to be confirmed by the testimonies of his Western academic colleagues. No doubt Greimas supported the famous Lithuanian archeologist in the USA Marija Gimbutas who came forward with the matristic theory of Old Europe. He also published two reviews of Gimbutas's books (Greimas 1957b; Greimas 1990). 
Encyclopédie de la Pléiade does not contain any names of women, he has not studied any women's works. It is also difficult to find the names of women writers in his French-language texts, but there are plenty that treat women as an aesthetic object. The patriarchal view of "the fair sex" defines one of the limitations of Greimas's intellectual work.

His dismissal of late Soviet Lithuanian literature is another limitation that marks Greimas's attachment to authors and aesthetic preferences of his youth, especially the ones formulated by the horizon of expectations of interwar Lithuania. In some cases, his preference for a French-oriented system of guidelines and comparisons between the national and Western literatures also prevented him from understanding new and valuable works that required a different reading code.

When commenting on the difference between his own French and Lithuanian works, Greimas claims that "between these two there is an abyss" (Letter to Ivar Ivask, 28 ${ }^{\text {th }}$ June, 1977; see Sverdiolas, 2017: 267). However, we would like to disagree with this. Our guess is that while writing Lithuanian essays, i.e. developing the genre that was closest to him, Greimas could partly realize his own essayist and maybe even poetic abilities, so he allowed himself to take up topics that he did not dare to touch in the French press due to an inner censor or cultural taboos.

His Lithuanian literary critique was a sort of laboratory for ideas, since plenty of conceptions that were later developed in Parisian seminars or theoretical works were first tried out (or at least mentioned) in his Lithuanian essays. As he wrote in a letter $\left(13^{\text {th }}\right.$ October, 1988) to a friend from his youth in the USA, the artist Aleksandra Kašubienè, both literature and philosophy and his "science" are one and the same: "in the best case, it is just accurately posed questions" (Greimas, Kašuba 2008: 33).

\author{
Loreta Mačianskaitè \\ Loperpetua@gmail.com \\ Lietuvių literatūros ir tautosakos institutas \\ Antakalnio g. 6 \\ 10308 Vilnius \\ LIETUVA / LITHUANIA
}


MAČIANSKAITE்

\section{References}

Barthes, R. 1953. Le Degré zéro de l'écriture. Paris: Éditions du Seuil.

Bikulčius, V. 2016. „Vilniaus pokeris“ Prancūzijos kritikų akimis. - Literatūra ir menas, 06.05, http://literaturairmenas.lt/literatura/vytautas-bikulcius-vilniaus-pokerisprancuzijos-kritiku-akimis (13.06.2019).

Broden, T. 2011. Toward a Biography of Algirdas Julius Greimas. - Lituanus, 57 (4), 5-40, http://www.lituanus.org/2011/11_4_01Broden.html (30.09.2019).

Daugirdaitè, S. 2012. Lietuvių modernizmas be feminu. - L. Mačianskaitè, ed., Antanas Škèma ir slinktys lietuvių literatūroje. Vilnius: Lietuvių literatūros ir tautosakos institutas, 52-68.

Gavelis, R. 2009. Vilnius Poker: novel. Transl. by E. Novickas. Rochester, NY: Open Letter Press, University of Rochester Press.

Gavelis, R. 2014. Vilnius Poker: roman. Transl. by M. Le Borgne. Arles: Monsieur Toussaint Louverture.

Greimas, A. J. 1943. Cervantes ir jo Don Kichotas. - Varpai, 1, 221-227.

Greimas, A. J. 1944a. Verlaine'as - žmogus ir poetas . - Varpai, 2, 123-136.

Greimas, A. J. 1944b. Gražinos Tulauskaitès Vejjo smuikas. - Varpai, 2, 388-390.

Greimas, A. J. 1949. Lietuvių kalbos senumas ir jaunatvè. - Lietuvis, 21.10, 4.

Greimas, A. J. 1954. Mintys apie Henriką Radauską ir jo strèlès vietą lietuviškame danguje. - Literatūros lankai, 4, 20.

Greimas, A. J. 1955. Corneille aktualumas. - Literatūros lankai , 6, 25.

Greimas, A. J. 1956. Littérature lithuanienne. - R. Queneau, ed., Encyclopedie de la Pleiade, 2, special issue Litteratures occidentales. Paris: Gallimard, 1438-1450.

Greimas, A. J. 1957a. 'Lytingumas' lietuvių literatūroje. - Santarvè, 1, 20-21.

Greimas, A. J. 1957b. Lietuvių senoji simbolika ir jų dabarties būdas. - Santarvè, 2, 96.

Greimas, A. J. 1963. Algimantas Mackus arba namų ieškotojas. - Metmenys, 7, 112-117.

Greimas, A. J. 1966. Sémantique structurale: recherche et méthode. Paris: Larousse.

Greimas, A. J. 1966. Mitai ir ideologijos. - Metmenys, 12, 9-27.

Greimas, A. J. 1972. Tomo Venclovos beveik beprasmè poezija. - Metmenys, 23, 9-17.

Greimas, A. J. 1980. Ašara ir poezija: Vienos Marcelijaus Martinaičio poemos analizè. - Metmenys, 40, 44-73.

Greimas, A. J. 1987. De l'imperfection. Périgueux: Pier Fanlac.

Greimas, A. J. 1988. Maupassant: the Semiotics of Text: Practical Exercices. Transl. by P. Perron, John Benjamins Publishing Company.

Greimas, A. J. 1990. Europa be europiečių.- Metmenys, 59, 157-161.

Greimas, A. J. 1991a. Iš arti ir iš toli. Literatūra, kultūra, grožis: straipsnių rinkinys. Ed. by S. Žukas. Vilnius: Vaga.

Greimas, A. J. 1991b. Baltos lankos. Occasional column. - Literatūra ir menas. 13.07, 6.

Greimas, A. J. 1991c. La France est gagnée par 'l'insignifiance'. - Le Monde, 22.10.

Greimas A. J. 2012. Baltos lankos. Occasional column. - Baltos lankos, 30, 158-192.

Greimas A. J., Kašuba, A. 2008. Algirdo Juliaus Greimo ir Aleksandros Kašubienès laiškai 1988-1992. Vilnius: Baltos lankos.

Nastopka, K. 2017. Semiotikas dar iki semiotikos. - Varpai, 36, 7-16. 
French-Lithuanian Universe of Literary Critique by Greimas

Radauskas, H. 1950. Strèlè danguje: eileraščiai. Chicago: V. Saulius.

Séry, M. 2015. La Lituanie au temps où l'on marchait sur la tête. - Le Monde, 04.06, https://www.lemonde.fr/livres/article/2015/06/04/la-lituanie-au-temps-ou-l-onmarchait-sur-la-tete_4646899_3260.html (30.09.2019).

Škèma, A. 1994. Rinktiniai raštai, 1. Vilnius: Vaga.

Sverdiolas, A., ed. 2017. Algirdas Julius Greimas: asmuo ir idejos I. Vilnius: Baltos lankos. Venclova, T. 1972. Kalbos ženklas: eilèraščiai. Vilnius: Vaga. 